Van de Walle, S. (2018, accepted). Explaining variation in perceived managerial autonomy and direct politicization in European public sectors. International Review of Administrative Sciences.

\title{
EXPLAINING VARIATION IN PERCEIVED MANAGERIAL AUTONOMY AND DIRECT POLITICIZATION IN EUROPEAN PUBLIC SECTORS
}

\author{
Steven Van de Walle
}

22 November 2017

\begin{abstract}
Public sector reforms aimed at 'making the managers manage', granted public managers autonomy and tried to depoliticize the administration. There is substantial variation in the degree of direct politicization and in managerial autonomy. This article tests four sets of hypotheses to explain variation in perceptions of direct politicization and managerial autonomy in European public sectors. Data from a new survey in 15 countries among several thousands of top public sector managers in central government are used. Findings show that variation in perceived direct politicization and managerial autonomy is partially determined by the formal status of an organization as agency, and the hierarchical position of the manager within the organization. Managers from very large organizations also experience more autonomy, but organization size has no impact on perceived politicization. The policy field within which the respondent's organization is situated has mixed effects. The article also finds that the models are better at explaining the variation in perceived managerial autonomy than that in direct politicization.
\end{abstract}

Keywords: politicization, managerial autonomy, top civil servants 


\section{Introduction}

Public administration reforms initiated in the 1980s and 1990s had the dual objective of depoliticizing the senior civil service and granting senior public managers more managerial autonomy. 'Letting the managers manage' means freeing them from political interference in managerial decisions, but also granting them the autonomy from superior bodies to manage their organization (Kettl, 1997; Pollitt and Bouckaert, 2004; Bezes and Jeannot, 2017). NPM reforms have meant that public organizations and their managers have been granted more autonomy, both vertically through a decentralization of decisions on administrative matters to (line) managers, and horizontally through structural reconfigurations such as the establishment of autonomies agencies (Van de Walle, 2016). According to this logic, managers are recruited for their skills in running government operations, rather than for their political feel or party affiliation.

The objectives of the NPM were not just about 'a decrease in political control and increasing administrative influence and institutional autonomy' (Christensen \& Laegreid, 2001: 74), but just as much about reasserting political control over the administration. Suleiman (2003), but also many others, have argued a move to NPM went together with deprofessionalization of the bureaucracy and politicization, while Dahlström \& Pierre (2011) found that politicization has also been used as a coordination strategy when public organizations have high autonomy.

Far from converging to a managerialist and purely merit-driven system at the top of modern public administrations, wide country-level, organization-level and individual-level variety continues to exist in the extent of direct politicization and managerial autonomy in government organizations. The purpose of this article is to scrutinizing the linkage between structural factors and managerial autonomy and direct 
politicization as perceived by top public managers in European countries, using a novel dataset. As such, the article wants to contribute empirically to the literature on politicization and autonomy. It also wants to provide public sector reformers with information about which parts of central government and which managers experience most politicization and experience the least autonomy. From this, recommendations for structural solution can be derived.

The article first reviews the literature on direct politicization and patronage as well as managerial autonomy in European public sectors following public administration reforms, with a particular focus on empirical work that has compared organizations and countries. It then develops four sets of hypotheses to explain variation in direct politicization and managerial autonomy in central government organizations. Subsequently, the data is introduced and descriptive data is presented, followed by two regression models. Findings are discussed and conclusions are drawn both on the variation of politicization and that of managerial autonomy.

\section{Explaining individual-level variation in perceived politicization and managerial autonomy}

The strict separation between politics and administration, or between steering and rowing in the NPM discourse, reflects a belief in the existence of a politicsadministration dichotomy. This approach certainly has analytic value, yet is not very good at reflecting realities on the field (Svara, 2011: Spence, 1997). Especially at the strategic level of public organizations, there tends to be a merging or conflation of political and management activities. This has been called the 'purple zone', located in between the blue zone of politics and the red zone of career public managers (Bellò \& 
Spano, 2015; Alford et al. 2016), where managerial autonomy and direct politicization or patronage come in many variations. This is why studying perceptions of top public managers is important and worthwhile.

The purpose of this article is to explain variation in politicization and managerial autonomy in public sector organizations in Europe, as perceived by top public sector managers. The focus of most current research on determinants of politicization and managerial autonomy has been on the organizational level (do organizations have autonomy, and are organizations politicized), rather than on individual-level variance. Where such individual-level studies have been conducted (see e.g. Lonti, 2005), these tended to have rather low explanatory power, partly due to the limited availability of independent variables. In addition, the focus of much of the current research has been on formal and country-level determinants such as the nature of the political system or political culture, or the legal status of an organization. Explanatory approaches that focus on individual-level variance in perceived managerial autonomy and direct politicization are scarce. The analysis in the current article will test a number of explanations for the individual-level variation in perceived managerial autonomy and direct politicization.

Before turning to the hypotheses, we first introduce the key concepts. When organization have autonomy this means there is a 'primacy of managerial practices over bureaucracy' (Verhoest et al., 2010: 6), and that the organization is able to work with limited external constraints (Maggetti, 2007). . Part of the motivation to establish agencies, where they did not already exist, was to depoliticize public tasks (James \& Van Thiel, 2011; Majone, 2001). This is not only useful for public organizations themselves, but it may also create credibility for the politicians who in this way signal that they will refrain from interfering. Grønnegaard Christensen (2001: 119) argues that 
granting autonomy to the bureaucracy is also a strategy for politicians to reduce political uncertainty, and to deflect blame when things go wrong (Hood, 2010; James et al., 2016). In this article we use the perceived managerial autonomy as dependent variable to mean the extent of autonomy managers perceive to have in making decisions about issues such budget allocations, hiring and firing, or contracting out. Managerial autonomy refers to autonomy in 'the choice and use of input' (Verhoest et al., 2004: 105). This concerns production factors such as HR, finance, organization, housing or logistics (Verhoest et al. 2004). Managerial autonomy is one of six dimensions of organizational autonomy as defined by Verhoest et al. (2004).

Politicization is a method for reducing information asymmetry and exercising control, and for patronage (Gherghina \& Kopecký, 2016). Bauer and Ege define it as 'the substitution of neutrality by introducing political (i.e. non-meritocratic and - given the policy dossiers at stake - non-objective) considerations into the decision-making process' $^{\prime}$ (2012: 408). There are different types of politicization, for instance direct and formal, through appointing people for political reasons (Rouban, 2003; Peters \& Pierre, 2004: 2), or professional and functional politicization which refers to the actual behaviors of civil servants, more in particular their responsiveness to the politicians' policy position. The former can of course be used to achieve the latter (Bauer \& Ege, 2012). The focus in this article is on direct politicization through bureaucratic appointments.

There is considerable variation in how public managers perceive their managerial autonomy and the extent of politicization in their organization. We formulate hypotheses which put forward a number of competing claims related to the individual and organizational context of the respondent. This study does not look at 
broader system characteristics that are commonly used to explain country variation in direct politicization or managerial autonomy because our focus is not in the first place to explain country variation. Also, the nature of the survey data used in this article did not allow us to collect information on the exact political context of the respondents' organizations, due to confidentiality reasons.

First, structural explanations are important. For public organizations that have agency status devolution has presumably been intentional in order to depoliticize executive tasks and to allow them to operate autonomously devoid from burdensome bureaucratic controls. It is thus to be expected that public managers working for agencies report more managerial autonomy and less politicization (Yesilkagit \& Van Thiel, 2008; Di Mascio, 2013). Despite considerable difference in how much autonomy is actually granted to agencies (Van Thiel, 2012) or differences in when these agencies have been founded, this has been confirmed in earlier work by Kopecký et al. (2016) for politicization, or by Lonti (2005) and Hall et al. (2011) for autonomy. Egeberg and Trondal (2009) also found that agency officials pay less attention to political signals, than those working for (ministerial) departments. More recent explanatory work on politicization found that political appointments are more common in ministries than in agencies (Kopecký et al., 2012). This is confirmed by a 2016 study by Kopecký et al. that also found lower politicization in executing institutions as compared to ministries. Kopecký et al. (2016: 421) for this reason recommended scholars pay attention to institutional types in future research on politicization. This brings us to the following hypotheses:

Hla: Public sector managers working in agencies perceive lower direct politicization. 
Hlb: Public managers working in agencies perceive having higher managerial autonomy.

A second structural factor is organization size. It is difficult for political principals to micromanage and keep control of all managerial decisions in large organizations. Size also gives organizations managerial capacity as well as political clout to claim their autonomy. We thus expect high managerial autonomy for large organizations. At the same time, their size also means organizations can no longer lead a quiet life, and that they become subject to more scrutiny (Verhoest et al., 2011: 215), or that they become a more desirable political spoil. The information asymmetry between principal and agent that arises as a result of size may also increase the political principal's need to politically appoint officials in order to control the agent. Lioukas et al. (1993), who studied perceptions of managerial autonomy among Greek SOEs, found, amongst others, that factors such as political visibility and organization size increased the likelihood of intense controls. Van Thiel et al. (2012: 421), however, suggested that in case of organizations with high salience and big budgets de facto political control often goes hand in hand with high managerial autonomy. Based on these findings, we formulate the following hypotheses:

H2a: Public sector managers working in large organizations perceive higher direct politicization.

H2b: Public managers working in large organizations perceive higher managerial autonomy.

Size is related to visibility, but visibility of an organization is not entirely determined by its size. Earlier scholarship has concentrated on the (political) visibility 
of organizations and suggested that low visibility leads to high autonomy (Hall et al., 2011). Lonti (2005) found that agencies in the periphery enjoy more autonomy than those in the core. Likewise, Antonsen and Jørgensen (1997) surveyed Danish state organizations and found that high publicness is associated with low autonomy. We assume that politicians will not bother much about organizations in very technical policy areas, because these lack salience. In agency research, Verhoest et al. (2011: 215) predicted that agencies in the area of welfare and social policy are more politically salient, because of their direct effect on citizens, and will therefore be granted less autonomy. Hall et al. (2011: 29) suggested that agencies that work in the shadow of topical and controversial policy issues' are more likely to have autonomy. We thus expect lower direct politicization and higher managerial autonomy in more technical policy areas, and higher direct politicization and lower autonomy in less technical and presumably more politically salient fields, where policies have immediate and visible impact. This is especially the case for welfare-related policy areas (Verhoest et al., 2011: 215).

H3a: Public managers working in welfare-related fields, will perceive higher direct politicization and lower managerial autonomy.

H3b: Public managers working in technical policy fields will perceive lower direct politicization and higher managerial autonomy.

Fourth, we assume that a public manager's position influences the way how he or she perceives politicization and autonomy. Top level people are expected to experience high managerial autonomy, but also high direct politicization - if politicians interfere, they do it through the top. Political appointments also happen more at the top than at lower levels (Kopecký et al. 2012). For politicization, we assume that political 
pressure works primarily through the top officials, meaning that lower ranked officials are shielded from direct political influence by their superior. For managerial autonomy, we assume that higher ranked officials experience more autonomy, whereas lower ones face more constraints. We also assume top officials develop ways of dealing with outside influence, and that when they have a good working relationship with their principal, they can craft more autonomy. This follows Lonti's (2005) argument that politicians want to avoid risk when granting autonomy.

H4a: Higher-positioned top public sector managers in an organization perceive more managerial autonomy but also higher direct politicization.

H4b: Public managers who frequently interact with their political principal perceive to have higher managerial autonomy.

The four sets of hypotheses are not mutually exclusive. Size and policy fields are for instance related, and agency status is related to policy field. Hence the need for testing them simultaneously. We do not have prior expectations about differences in the size of the effects. The literature is silent about this, with the exception of Kopecký et al. (2016) who found variation in politicization between policy sectors to be lower than that between agencies and ministries.

\section{Data}

We use data from the COCOPS Top Public Executive Survey. This is a unique open access dataset based on a survey of central government top managers in ministries and agencies in a series of European countries (See Hammerschmid et al. 2016 for details). The survey targeted the entire population of the top three levels of managers (positions comparable to that of secretary-general, director-general and director) in 
central government administration. In Germany and Spain, also regional levels have been included. Respondents were identified by a national research team in each of the countries following a shared mapping template. This resulted in a sampling frame in these 15 countries of 19.053 senior public sector executives. The national research teams also collected contact information and decided on the best possible approach to stimulate responses. In most countries high-level endorsement from government bodies or leading civil servants was sought to stimulate response. This focus on the top three levels corresponds to the approach taken by Evans and Rauch (1999) in their study of civil service Weberianness, but stops short of Meyer-Sahling and Veer's (2012) focus on the top four management levels in CEE countries in their study of senior civil service politicization.

The COCOPS survey used a standardised instrument translated in the local language, and was administered electronically. Some research teams also employed paper-based questionnaires either for the entire survey or as a non-response follow up. Total average response rate for the countries included in this article was $29,8 \%$, which is high given the type of population. A detailed breakdown of the sampling frame and response rates can be found in Appendix B. A total of 4.489 answers were collected on politicization and 5.002 on management autonomy. The sample is lower for politicization because respondents have been given the explicit option to indicate they are not able to assess this, whereas this option was not available when answering the questions on autonomy. The survey does not claim full representativeness for the data but can be regarded as a good proxy. Detailed checks on representativeness were not possible because of very strict confidentiality requirements when surveying these top decision makers. For this reason, we could also not collect additional information about 
the respondents' organization beyond that what was asked in the survey. Detailed information on the fieldwork per country is available in Hammerschmid et al. (2013).

\section{Using perceptions to study variation in direct politicization and managerial}

\section{autonomy}

This article uses perception data to study variation in direct politicization and managerial autonomy based on the perceptions of top public managers. Measuring direct politicization or patronage is particularly difficult in systems where political appointments do not formally exists, unlike e.g. the United States’ spoils system. In systems such as the latter, politicization as occurring through direct political appointments is arguably 'easier' to study because of its official and overt character (see e.g. Lewis, 2010; Krause et al., 2006). There is a longer tradition in the field of relying on perceptions rather than on other sources of data, because of the inaccessibility of such data (Charron et al., 2016). Examples of such perception-based work are the work by Mayntz \& Derlien (1989) who collected attitudes to politicization among German top civil servants, Bauer and Ege's (2012) study of perceptions of middle and senior-level European Commission officials (2012) on the importance of party affiliation and ideology, or Bellò \& Spano’s (2015) survey of Italian public managers about their perception of political influence in, amongst others, decision making and promotion, where they found pervasive direct politicization. Related work asked about senior American Federal government officials’ perception of mechanisms of political influence, and the main actors exerting influence (Waterman et al., 1998; Furlong, 1998). This article measures direct politicization or patronage in relation to senior-level appointments as perceived by top public managers. This means we are 
primarily interested in patronage intended to control administrative bodies, and less in patronage as a material incentive for party supporters (Di Mascio, 2013)

Measuring managerial autonomy is also difficult, because formal autonomy, as established in legal documents or organizational configurations, is not the same as de facto autonomy (Yesilkagit \& Van Thiel, 2008; Maggetti, 2007). Scholars have mainly depended on perception studies in order to get a more accurate picture of managerial autonomy on the field (Maggetti \& Verhoest, 2014). A major initiative in this respect has been the COBRA network (Comparative Public Organization Data Base for Research and Analysis) which organized surveys on organizational autonomy in government agencies in European countries. Other studies have looked more broadly at management autonomy and how it is perceived, yet focused on single countries (Lonti, 2005; Hall et al., 2011; Hoque et al., 2004). This work for instance found differences in autonomy perceptions depending on the centre/periphery position of the organization, its agency status, and the extent of strong organized interests in the organizational environment.

\section{Operationalization}

\section{Direct politicization}

In line with the literature on politicization used in the introductory sections of this article (Peters \& Pierre, 2004; Bauer \& Ege, 2012), we will work with a variable that is conceptually closests to the direct politicization as we want to measure it, and one that is relevant for a group of respondents who are top public sector managers: 'What is your view on the following statement: Politicians regularly influence seniorlevel appointments in my organization' (1. Strongly disagree / 7. Strongly agree) $)^{\mathrm{i}}$. 


\section{Managerial autonomy}

Perceived managerial autonomy was measured by asking respondents to indicate whether they had a lot of autonomy in six areas: budget allocations; contracting out of services; promoting staff; hiring staff; dismissing of removing staff; and making changes in the structure of the organization. Respondents could answer using a Likert scale ranging from very low autonomy (1) to very high autonomy (7). We specifically asked for respondents' own perspective, rather than about their organization's formal autonomy. Despite the conceptual variation of the items, all six items load on a single factor explaining 59,6\% of total variance (Cronbach's Alpha $=.864)$, and for this reason items were combined into a new managerial autonomy index using factor scores.

\section{Independent variables}

Respondents could themselves indicate to which policy field their organization belongs. Because of the complex tasks of many public organizations, they could indicate more than one field. Organization size is a self-report of the number of employees working for the organization the respondent belongs to. The agency variable captures whether the organization the respondent works for is a ministry or an agency, based on a simple self-report Because the main purpose of the survey was not to study

organizational differences, further differentiation of agency types is not available. Respondents were also asked which position they occupy within the organization: the top, the second or the third hierarchical level. Finally we asked how often they typically interact with their responsible minister, on a six-point scale ranging from never to daily. 


\section{Control variables}

To control for sociodemographic differences in answering behavior and for nonresponse patterns, a number of individual-level control variables have been added. The respondent's age in three categories, gender, and number of years working in the public sector. Because of the type of respondents (high level bureaucrats) and the sensitivity of some of the questions, we expected many respondent to refuse providing socio-demographic information. For this reason these items were inserted at the end of the questionnaire. We also created a missing category on each of the socio-demographic variables and added this to the estimation in order to maximize the total $\mathrm{N}$ of the models, rather than introducing other types of biases through data imputation or list-wise case removal of in between 11.1 and 12.7 per cent. Country fixed effects are added using country dummies. No further country-level variables were added because this article's focus is not on explaining country differences.

\section{Descriptive findings: country-level data for direct politicization and managerial autonomy}

Before proceeding to the main analysis, we first present descriptive findings in the form of country-level data for direct politicization and managerial autonomy. 
Figure 1: Perceived direct politicization

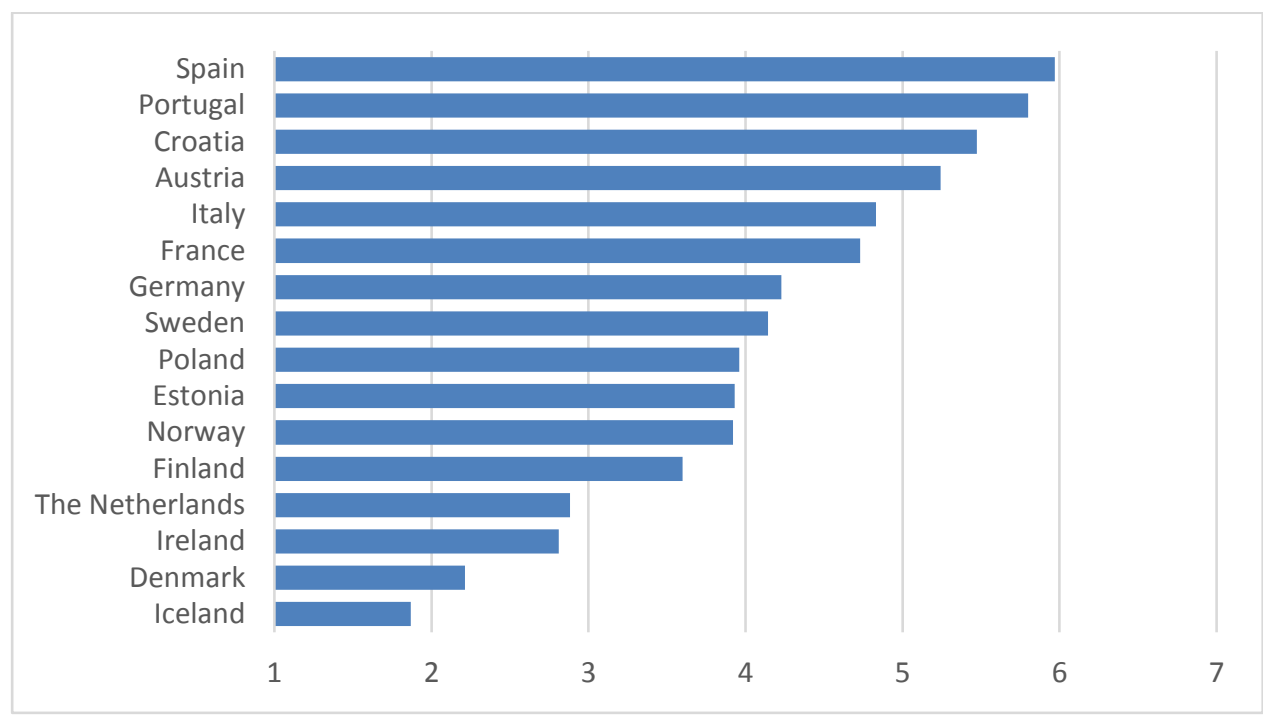

Politicians regularly influence senior level appointments in my organization, $1=$ totally disagree, $7=$ totally agree.

Figure 1 shows that direct politicization as perceived by central government top public managers is highest in Portugal and Spain as well as in Croatia. It is lowest in most Nordic country as well the Netherlands and Ireland. A similar patterns emerges when looking at perceived managerial autonomy. Top public managers in the Netherlands perceive to have the highest managerial autonomy of all countries included in the study, followed by those in the Nordic countries, except Finland. Perceived managerial autonomy is the lowest in the Southern European countries Spain, Portugal and Italy. 
Figure 2: Managerial autonomy index

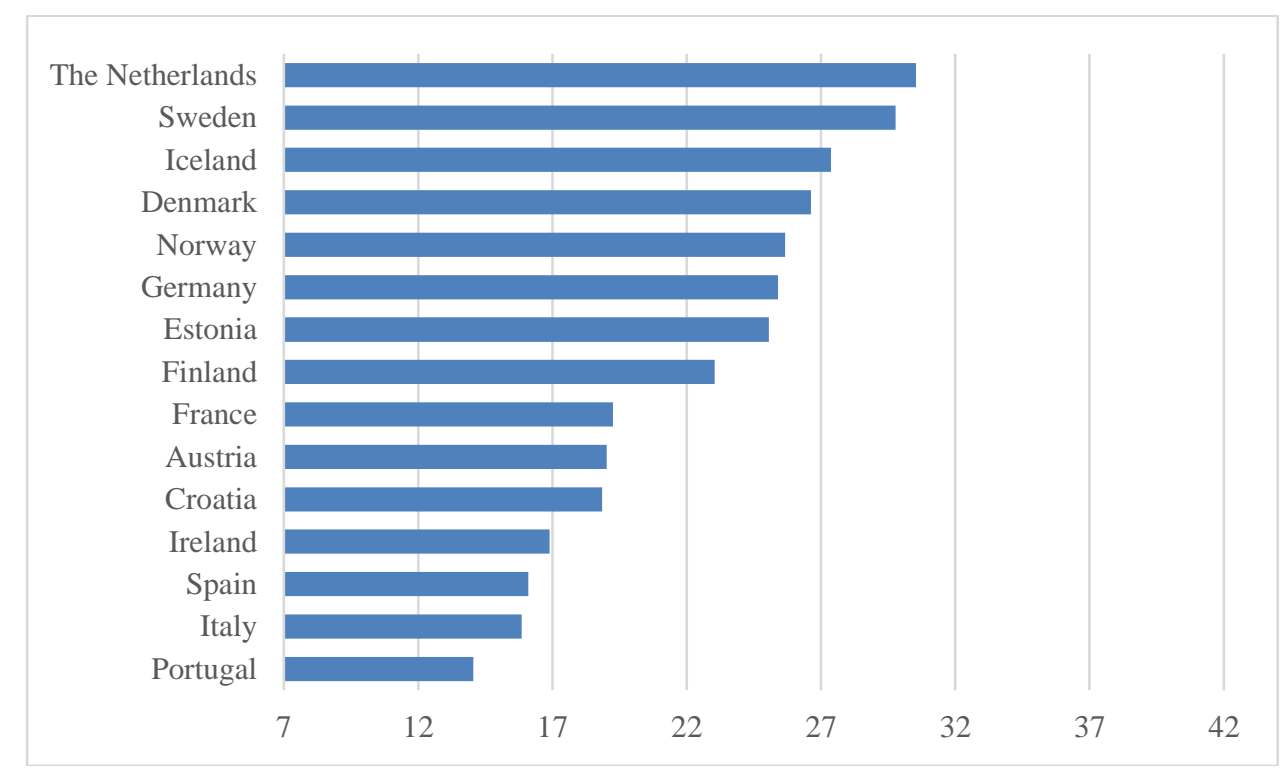

Managerial autonomy index -6 items, 1=very low autonomy, $7=$ very high autonomy.

Correlation between the managerial autonomy index and the direct politicization variable is high $(r=-.342, p<.001)$ at the individual level (equal country weights applied), and even higher at the country level $(r=-.669, p<.01)$. Yet, as we have mentioned above, the two form different dimensions. Patterns are comparable, but there are some noteworthy differences between both indicators. Managers in Ireland for instance experience relatively low autonomy, but this is not matched by high politicization. A country such as Sweden combines very high managerial autonomy with, in comparison, relatively higher levels of politicization.

\section{Analysis: Explaining variance}

We subsequently ran two separate linear regressions with perceived politicization and perceived managerial autonomy as dependent variables. Politicization is a sensitive topic. For this reason, even in an anonymous survey, respondents often decide not to answer such questions. This was especially the case in 
some countries included in the survey. Hungary, Lithuania, and Serbia were not included in the analysis because of high item nonresponse. Poland and the UK were not included because not all relevant independent variables had been included in the survey questionnaire in these countries. Nevertheless, a robust multi-country dataset remains. Findings are reported in table 1 . There were no indications for multicollinearity problems as reflected in the VIFs. A table in the appendix reports correlations between the independent variables. There are many similarities but also differences between the models for politicization and managerial autonomy. The first major difference is that the explained variance of the managerial autonomy model is considerably higher - even double - than that of the politicization model. We discuss the findings below.

Table 1: Linear regression on perceived direct politicization and managerial autonomy

\begin{tabular}{|c|c|c|c|c|}
\hline & \multicolumn{2}{|c|}{ perceived politicization } & \multicolumn{2}{|c|}{ perceived managerial } \\
\hline & $\beta$ & S.E. & $\beta$ & S.E. \\
\hline agency status (H1) & $-0,904$ & $0,082 * * *$ & 0,290 & $0,031 * * *$ \\
\hline \multicolumn{5}{|l|}{ org. size (ref. is < 100) $(\mathrm{H} 2)$} \\
\hline org size is between 100 and 499 & 0,092 & 0,090 & 0,034 & 0,034 \\
\hline org size is between 500 and 999 & 0,067 & 0,109 & 0,035 & 0,041 \\
\hline org size is 1000 or more & 0,007 & 0,097 & 0,135 & $0,036 * * *$ \\
\hline \multicolumn{5}{|l|}{ policy field (H3) } \\
\hline infrastructure, env., agriculture, transportation & 0,023 & 0,088 & 0,120 & $0,033 * * *$ \\
\hline finance and economic affairs & $-0,298$ & $0,083 * * *$ & 0,033 & 0,031 \\
\hline general government, foreign affairs & 0,082 & 0,083 & 0,016 & 0,031 \\
\hline employment, health, social prot., welfare & 0,156 & 0,084 & 0,010 & 0,031 \\
\hline education, recreation, culture, religion & $-0,122$ & 0,095 & 0,031 & 0,035 \\
\hline other & $-0,118$ & 0,082 & 0,025 & 0,031 \\
\hline justice, public order, safety, defence & 0,089 & 0,092 & 0,054 & 0,034 \\
\hline \multicolumn{5}{|l|}{ hierarchical level (ref. is first) (H4a) } \\
\hline second & 0,582 & $0,084 * * *$ & $-0,462$ & $0,032 * * *$ \\
\hline third & 0,938 & $0,097 * * *$ & $-0,771$ & $0,037 * * *$ \\
\hline interaction freq. w. responsible minister $(\mathrm{H} 4 \mathrm{~b})$ & $-0,037$ & 0,026 & 0,083 & $0,010 * * *$ \\
\hline \multicolumn{5}{|l|}{ control variables } \\
\hline resp is female & $-0,015$ & 0,067 & $-0,046$ & 0,025 \\
\hline sex is missing & 0,136 & 0,224 & $-0,140$ & 0,083 \\
\hline \multicolumn{5}{|l|}{ age (ref. is 45 or less) } \\
\hline age $46-55$ & 0,161 & 0,090 & 0,015 & 0,034 \\
\hline age over 55 & 0,244 & $0,103 *$ & $-0,043$ & 0,039 \\
\hline age is missing & 0,053 & 0,315 & 0,088 & 0,112 \\
\hline \multicolumn{5}{|l|}{ public sector experience (ref. is 20 years + ) } \\
\hline less than 5 years public sector experience & 0,022 & 0,143 & 0,185 & $0,053 * * *$ \\
\hline $5-10$ year public sector experience & 0,428 & $0,128 * *$ & 0,054 & 0,047 \\
\hline $10-20$ year public sector experience & 0,124 & 0,085 & 0,038 & 0,032 \\
\hline $\begin{array}{l}\text { public sector experience not indicated } \\
\text { country dummies (ref. is Finland) }\end{array}$ & $-0,180$ & 0,226 & 0,126 & 0,083 \\
\hline
\end{tabular}




\begin{tabular}{|c|c|c|c|c|}
\hline Germany & 0,837 & $0,141 * * *$ & $-0,169$ & $0,054 * *$ \\
\hline France & 0,669 & $0,139 * * *$ & $-0,290$ & $0,053 * * *$ \\
\hline Spain & 1,842 & $0,160 * * *$ & $-0,574$ & $0,061 * * *$ \\
\hline Italy & 1,037 & $0,196 * * *$ & $-0,863$ & $0,073 * * *$ \\
\hline Estonia & 0,411 & $0,155^{* *}$ & 0,061 & 0,056 \\
\hline Norway & 0,169 & 0,150 & 0,302 & $0,054 * * *$ \\
\hline Austria & 1,397 & $0,135 * * *$ & $-0,406$ & $0,051 * * *$ \\
\hline Portugal & 2,249 & $0,178 * * *$ & $-1,105$ & $0,066 * * *$ \\
\hline Ireland & $-0,961$ & $0,144 * * *$ & $-0,713$ & $0,053 * * *$ \\
\hline Sweden & 0,870 & $0,132 * * *$ & 0,566 & $0,048 * * *$ \\
\hline Iceland & $-1,363$ & $0,177 * * *$ & 0,194 & $0,067 * *$ \\
\hline Croatia & 1,917 & $0,199 * * *$ & $-0,548$ & $0,074 * * *$ \\
\hline The Netherlands & $-0,638$ & $0,176 * * *$ & 0,532 & $0,066 * * *$ \\
\hline Denmark & 0,826 & $0,097 * * *$ & 0,278 & $0,072 * * *$ \\
\hline (Constant) & 3,424 & $0,226 * * *$ & 0,187 & $0,084 *$ \\
\hline $\mathrm{N}$ & \multicolumn{2}{|c|}{4.255} & \multicolumn{2}{|c|}{4.621} \\
\hline adjusted $\mathrm{R}^{2}$ & \multicolumn{2}{|c|}{0,283} & \multicolumn{2}{|c|}{0,418} \\
\hline
\end{tabular}

\section{Findings for direct politicization}

As expected (H1a), respondents working for an agency rather than a department perceive less direct politicization. They work at a structural distance from political actors, making interference harder. This confirms Kopecký et al. (2016)’s study, as well as the work by Di Mascio (2013)which found stronger patronage in ministries than in executing institutions. Organization size does not appear to have an effect (H2a). An explanation for this could be that there are in fact two potentially competing processes at work: large organizations attract political attention, yet are also harder to meddle with. There is just one policy field effect (H3). Managers working the field of economic affairs and finance report less politicization,. This is a highly technical field. This finding is again consistent with Kopecký et al. (2016), who found that public finance is often depoliticized. Still, no effect was found for equally technical fields, or for welfare policy where more politicization was expected. . Respondents lower in the hierarchy (i.e. below level one) perceive more politicization, and perceptions of politicization increase as respondents sit lower in the hierarchy. This is contrary to our hypothesis H4a that suggested that higher level managers shield lower levels from politicization. Likely explanations are that having intense contacts with politicians (as is the case for 
the highest ranked managers) changes the perception of politicians and their actions. Politicians interfering is perhaps seen as the normal way of interaction between politics and administration rather than as politicization. An alternative explanation is that the highest hierarchical levels do not even notice politicization anymore, through habituation, or because they have been appointed for political reasons and therefore see political interference as legitimate. A third explanation could be that managers at the highest level frequently invoke fake political pressure in order to strengthen compliance by their managers at level two and three, thereby influencing lower-level managers perception of political interference.

\section{Findings for managerial autonomy}

The model for managerial autonomy has an adjusted $\mathrm{R}^{2}$ of .418 , which is very high. There are some clear findings related to structural factors. Managers working in agencies also report more autonomy (H1b), which directly follows from the formal raison d'être of agencies. Public managers working for very large organizations report more managerial autonomy, thereby partially confirming $\mathrm{H} 2 \mathrm{~b}$. H2b only holds for very large organizations (>1000 employees), and not for other large organizations. The size effect can be explained in different ways. One is that their size allows them to capture and enforce their own autonomy vis-à-vis other actors, such as political principals or ministries responsible for finance and HR. It can also signal that very large organizations have more capacity to organize their own in-house processes regarding finance and HR. Just one policy field effect was found. Respondents active in the highly technical policy fields of infrastructure, environment, transport and agriculture report higher managerial autonomy $(\mathrm{H} 3 \mathrm{~b})$. The position of the respondent clearly matters Respondents at the top of an organization experience considerably higher managerial 
autonomy compared to those sitting at the second of third hierarchical level (H4a). In a way, this is logical, because the number one of an organization is in the end responsible for the overall management, while the number two and three fall under the top manager. We also find that managers reporting a high interaction frequency with their responsible minister experience higher managerial autonomy (H4b). This could suggest absence of adversarial political-administrative relations among this group.

Among the control variables, one surprising finding stands out. Managers with very low public sector experience (< five years) report significantly more managerial autonomy than those who have been working for the public sector most of their lives. This is a relatively small group of around seven per cent of the entire sample. There are two potential explanations for this. One is that these managers have been attracted from the outside with a specific mandate, and have for this reason been given very high autonomy. An alternative explanation is that these managers had very low expectations of managerial autonomy and expected considerable red tape within government before joining the public sector and were pleasantly surprised to find this was not the case.

\section{Discussion and conclusion}

This article presented novel data for direct politicization and managerial autonomy for a set of European countries. These show considerable variation across Europe. Using data from a survey among top public managers, four sets of explanations for the variance were tested. Overall, our findings confirm earlier studies on managerial autonomy and direct politicization (see, e.g. Verhoest et al., 2011; Kopecký et al., 2016; Lonti, 2005; Hall et al., 2011). Overall, though, our main lines of explanation appear to be better able to explain the variation in managerial autonomy than that in direct 
politicization. Several of the effects are also different across the models, confirming that (lack of) managerial autonomy and c politicization are different concepts.

First, there is a clear structural effect. Top public managers working in agencies report higher managerial autonomy and lower politicization. This is entirely what was expected, and also follows logically from the nature of public sector agencies. An effect of organization size is absent for politicization, and in the autonomy model a size effect was only found for managers working in very large organizations

We found limited and mixed effects of policy field, in both the autonomy and politicization models. While the limited effects we did find were in line with expectations, the findings are difficult to interpret or generalize. Working in more technical policy fields appears to be related to an experience of higher autonomy and less politicization, but the effect does not hold in a consistent way across the two models. Contrary to our expectations, no effect was found related to working in welfare policy fields. An explanation for this could be the high level of aggregation of policy field affiliation in the data and the difficulty of establishing how salient or politically visible a field is. Kopecký et al. (2016) for instance suggested that a field becomes more salient for politicization when higher opportunities for political graft and corruption exist (e.g. in industrial policy) whereas Verhoest et al., (2011: 215) defined salience mainly in terms of the impact of a policy or organization on citizens. Such competing approaches to salience make it hard to interpret statistical effects.

Public managers at the top of an organization experience both high managerial autonomy and low direct politicization, whereas managers at lower levels experience lower autonomy and higher politicization. This is straightforward to explain for managerial autonomy as we have indicated earlier and in line with the hypotheses, but more puzzling for politicization. One explanation could be that a high percentage of top 
managers at level one have been appointed politically. The alternative is that they have gotten used to political interference and have found ways of dealing with this while lower level managers have much less flexibility when it comes to dealing with or ignoring political demands. In this respect, a finding worth exploring is that when managers report a higher frequency of interaction with their responsible minister, they perceive more autonomy. There are number of potential explanations. This can indicate the existence of a good working relationship resulting in a well-functioning public service bargain. It can however also be interpreted as an indication that top managers have been appointed politically, and that for this reason they do not consider political interventions as politicization, and that their autonomy is normal given that control by the principal is already exercised trough political channels:

This study has a number of weaknesses. Only perceived managerial autonomy and perceived direct politicization have been measured, not formal managerial autonomy or actual direct politicization. An advantage of our approach is that we in this way are able to look beyond formal dimensions of autonomy, and capture autonomy as it is actually experienced. Perception measures of direct politicization help us move beyond analysis of formal politicization or expert surveys. Measurement of the dependent variables could be an explanation for the differences in the explained variance between the models. Measurement of managerial autonomy was more specific than that of politicization. Managerial autonomy was measured by inquiring after fairly specific and concrete actions, such as hiring people or allocating budgets. The measurement of direct politicization relied on a less specific survey item, using words such as 'regularly influence'. This makes the politicization variable more of a judgement rather than an observation of fact, resulting in more random variation. 
Despite these shortcoming, the use of multiple items to measure managerial autonomy, in combination with the massive population-based sample this article responded to calls for better measurement of politicization and autonomy (see, e.g., Fukuyama, 2013). Further research should also consider adding additional control variables such as variables looking at organization task type (see e.g. Lonti, 2005; Van Thiel \& Yesilkagit, 2014), at organization type (distinguishing between different types of agencies), or at political context variables such as government composition, the party landscape, party competition, distance from the nearest election or frequency of alternations in government composition (see Meyer-Sahling \& Veen, 2012). It could also move beyond our country fixed effects approach taken in this paper and start explaining the large country effects found within this survey of top public sector managers. 


\section{References}

Alford, J., Hartley, J., Yates, S., \& Hughes, O. (2016). Into the purple zone: Deconstructing the politics/administration distinction. American Review of Public Administration, online first, DOI: 10.1177/0275074016638481.

Antonsen, M., \& Jørgensen, T.B. (1997). The 'publicness' of public organizations. Public Administration, 75(2), 337-357.

Bauer, M. W., \& Ege, J. (2012). Politicization within the European Commission's bureaucracy. International Review of Administrative Sciences, 78(3), 403-424.

Bellò, B., \& Spano, A. (2015). Governing the purple zone: How politicians influence public managers. European Management Journal, 33(5), 354-365.

Charron, N., Dahlström, C., \& Lapuente, V. (2016). Measuring meritocracy in the public sector in Europe: A new national and sub-national indicator. European Journal on Criminal Policy and Research, 22(3), 499-523.

Christensen, J. (2001). Bureaucratic autonomy as a political asset. In: Peters, B.G. \& Pierre, P. (eds). Politicians, bureaucrats and administrative reform, London: Routledge, pp 119-131.

Christensen, J. G., Klemmensen, R., \& Opstrup, N. (2014). Politicization and the replacement of top civil servants in Denmark. Governance, 27(2), 215-241.

Christensen, T., \& Laegreid, P. (2001). New Public Management: The effects of contractualism and devolution on political control. Public Management Review, 3(1), 73-94.

Dahlström, C., \& Lapuente, V. (2010). Explaining cross-country differences in performance-related pay in the public sector. Journal of Public Administration Research and Theory, 20(3), 577-600. 
Dahlström, C., \& Pierre, J. (2011). Steering the Swedish state: Politicization as a coordination strategy. In: Dahlström, C., Peters, B.G., \& Pierre, J. (eds) Steering from the centre: Strengthening political control in Western democracies, Toronto: University of Toronto Press, pp. 193-211.

Dahlström, C., Teorell, J., Dahlberg, S., Hartmann, F., Lindberg, A., \& Nistotskaya, M. (2015). The QoG Expert Survey Dataset II. University of Gothenburg: The Quality of Government InstituteDi Mascio, F. (2013). Exploring the link between patronage and party institutionalization: an historical-institutional analysis of the Italian transition. Democratization, 21(4), 678-698.

Egeberg, M., \& Trondal, J. (2009). Political leadership and bureaucratic autonomy: Effects of agencification. Governance, 22(4), 673-688.

Evans, P. \& Rauch, J.E. (1999). Bureaucracy and growth: a cross-national analysis of the effects of Weberian state structures on economic growth. American Sociological Review, 64(5), 748-765.

Flinders, M., \& Buller, J. (2006). Depoliticisation: Principles, tactics and tools. British Politics, 1(3), 293-318.

Fukuyama, F. (2013). What is governance? Governance, 26(3), 347-368.

Furlong, S. R. (1998). Political influence on the bureaucracy: The bureaucracy speaks. Journal of Public Administration Research and Theory, 8(1), 39-65.

Gherghina, S., \& Kopecký, P. (2016). Politicization of administrative elites in Western Europe: an introduction. Acta Politica, 51(4), 407-412.

Hall, P., Nilsson, T., \& Löfgren, K. (2011). Bureaucratic autonomy revisited: informal aspects of agency autonomy in Sweden. Paper presented at the annual 
conference of the European Group for Public Administration (Bucharest: 7-10 September).

Hammerschmid, G., Oprisor, A., Štimac, V. (2013). COCOPS Executive Survey on Public Sector Reform in Europe: Research Report. Rotterdam: Erasmus University Rotterdam.

Hammerschmid, G., Van de Walle, S., Andrews, R. \& Bezes, P. (eds)(2016). Public administration reforms in Europe. The view from the top. Cheltenham: Edward Elgar.

Hood, C. (2001). Public service bargains and public service reform. In: Peters, B.G. \& Pierre, P. (eds). Politicians, bureaucrats and administrative reform, London: Routledge, pp 13-23

Hood, C. (2010). The blame game: Spin, bureaucracy, and self-preservation in government. Princeton: Princeton University Press.

Hoque, K., Davis, S., \& Humphreys, M. (2004). Freedom to do what you are told: senior management team autonomy in an NHS acute trust. Public Administration, $82(2), 355-375$.

James, O., \& Thiel, S. V. (2011). Structural devolution and agencification. In Christensen, T., \& Lægreid, P. (Eds). The Ashgate research companion to new public management. Aldershot: Ashgate, pp. 209-222

James, O., Jilke, S., Petersen, C., \& Van de Walle, S. (2016). Citizens' blame of politicians for public service failure: Experimental evidence about blame reduction through delegation and contracting. Public Administration Review, 76(1), 83-93.

Kettl, D. F. (1997). The global revolution in public management: Driving themes, missing links. Journal of Policy Analysis and management, 16(3): 446-462. 
Kopecky, P., Mair, P., \& Spirova, M. (eds)(2012). Party patronage and party government in European democracies. Oxford: Oxford University Press.

Kopecký, P., Meyer Sahling, J. H., Panizza, F., Scherlis, G., Schuster, C., \& Spirova, M. (2016). Party patronage in contemporary democracies: Results from an expert survey in 22 countries from five regions. European Journal of Political Research, 55(2), 416-431.

Krause, G. A., Lewis, D. E., \& Douglas, J. W. (2006). Political appointments, civil service systems, and bureaucratic competence: Organizational balancing and executive branch revenue forecasts in the American states. American Journal of Political Science, 50(3), 770-787.

Lewis, D. E. (2010). The politics of presidential appointments: Political control and bureaucratic performance. Princeton University Press.

Lioukas, S., Bourantas, D., \& Papadakis, V. (1993). Managerial autonomy of stateowned enterprises: Determining factors. Organization Science, 4(4), 645-666.

Lonti, Z. (2005). How much decentralization? Managerial autonomy in the Canadian public service. American Review of Public Administration, 35(2), 122-136.

Maggetti, M. (2007) De facto independence after delegation: A fuzzy-set analysis. Regulation \& Governance, 1(4), 271-294.

Maggetti, M., \& Verhoest, K. (2014). Unexplored aspects of bureaucratic autonomy: a state of the field and ways forward. International Review of Administrative Sciences, 80(2), 239-256.

Majone, G. (2001). Two logics of delegation agency and fiduciary relations in EU governance. European Union Politics, 2(1), 103-122. 
Mayntz, R., \& Derlien, H. U. (1989). Party patronage and politicization of the West German administrative elite 1970-1987- Toward hybridization? Governance, 2(4), 384-404.

Meyer-Sahling, J. H., \& Veen, T. (2012). Governing the post-communist state: government alternation and senior civil service politicisation in Central and Eastern Europe. East European Politics, 28(1), 4-22.

Norman, R. (2001). Letting and making managers manage: the effect of control systems on management action in New Zealand's central government. International Public Management Journal, 4(1), 65-89.

Peters, B. G. (2013). Politicisation: What is it and why should we care? In Neuhold, C., Vanhoonacker, S., \& Verhey, L. (eds). Civil Servants and Politics. Basingstoke: Palgrave Macmillan UK, pp. 12-24.

Peters, B.G., \& Pierre, J. (eds)(2004). The politicization of the civil service in comparative perspective: A quest for control. London: Routledge.

Pollitt, C., \& Bouckaert, G. (2004). Public management reform: A comparative analysis. Oxford: Oxford University Press.

Rouban, L. (2003). Politicization of the civil service. In: Peters, B.G., \& Pierre, J. (eds) Handbook of Public Administration. London: Sage, pp. 199-210.

Spence, D. B. (1997). Agency policy making and political control: Modeling away the delegation problem. Journal of Public Administration Research and Theory, 7(2), 199-219.

Suleiman, E. N. (2013). Dismantling democratic states. Princeton University Press.

Svara, J. H. (2001). The myth of the dichotomy: Complementarity of politics and administration in the past and future of public administration. Public Administration Review, 61(2), 176-183. 
Van de Walle, S. (2016). Reforming organizational structures. In: Van de Walle, S. \& S. Groeneveld, S. (eds). Theory and practice of public sector reform, London: Routledge, pp. 131-143

Van Thiel, S., Verhoest, K., Bouckaert, G. \& Laegreid; P. (2012). Lessons and recommendations for the practice of agencifiation. In: Verhoest, K., Van Thiel, S., Bouckaert, G., \& Lægreid, P. (Eds). Government agencies: practices and lessons from 30 countries. Houndmills: Palgrave Macmillan, pp. 413-439.

Van Thiel, S., \& Yesilkagit, K. (2014). Does task matter? The effect of task on the establishment, autonomy and control of semi-autonomous agencies. International Review of Administrative Sciences, 80(2): 318-340.

Verhoest, K., Peters, B. G., Bouckaert, G., \& Verschuere, B. (2004). The study of organisational autonomy: a conceptual review. Public Administration and Development, 24(2), 101-118.

Verhoest, K., Roness, P. G., Verschuere, B., Rubecksen, K., \& MacCarthaigh, M. (2010). Autonomy and control of state agencies: Comparing states and agencies. Houndmills: Palgrave Macmillan.

Waterman, R. W., Rouse, A., \& Wright, R. (1998). The venues of influence: A new theory of political control of the bureaucracy. Journal of Public Administration Research and Theory, 8(1), 13-38.

Yesilkagit, K., \& Van Thiel, S. (2008). Political influence and bureaucratic autonomy. Public Organization Review, 8(2), 137-153. 
Appendix A. Individual items used for the construction of the dependent variables

Managerial autonomy

In my position, I have the following degree of decision autonomy with regard to

1. Budget allocations

2. Contracting out services

3. Promoting staff

4. Hiring staff

5. Dismissing or removing staff

6. Changes in the structure of my organization

(1. Very low autonomy / 7. Very high autonomy)

\section{Direct politicization}

What is your view on the following statements:

1. Politicians regularly influence senior-level appointments in my organization (1. Strongly disagree / 7. Strongly agree / Cannot assess) 


\section{Appendix B. Responses per country}

\begin{tabular}{cccc}
\hline Country & $\begin{array}{c}\text { Invitations } \\
\text { sent }\end{array}$ & Response & $\begin{array}{c}\text { Response } \\
\text { rate }\end{array}$ \\
\hline Austria & 1.407 & 493 & $35,0 \%$ \\
Croatia & 650 & 176 & $27,1 \%$ \\
Denmark & 758 & 147 & $19,4 \%$ \\
Estonia & 913 & 318 & $34,8 \%$ \\
Finland & 1.742 & 703 & $40,4 \%$ \\
France & 3.403 & 587 & $17,2 \%$ \\
Germany & 1.955 & 445 & $22,8 \%$ \\
Iceland & 392 & 200 & $51,0 \%$ \\
Ireland & 980 & 375 & $38,3 \%$ \\
Italy & 971 & 172 & $17,7 \%$ \\
Norway & 1.197 & 334 & $27,9 \%$ \\
Portugal & 1.038 & 296 & $28,5 \%$ \\
Spain & 1.684 & 297 & $17,6 \%$ \\
Sweden & 1.293 & 523 & $40,4 \%$ \\
The Netherlands & 670 & 196 & $29,3 \%$ \\
\hline Total & 19.053 & 5.262 & \\
\hline
\end{tabular}


Appendix C. Descriptive statistics

\begin{tabular}{|c|c|c|c|c|c|}
\hline & $\mathrm{N}$ & Minimum & Maximum & Mean & $\begin{array}{l}\text { Std. } \\
\text { Deviation }\end{array}$ \\
\hline Direct politicization & 4489 & 1 & 7 & 4,10 & 2,31 \\
\hline managerial autonomy index & 5002 & $-1,72828$ & 2,14778 & 0,02 & 1,00 \\
\hline top hierarchical level & 5069 & 0,00 & 1,00 & 0,24 & 0,42 \\
\hline second hierarchical level & 5069 & 0,00 & 1,00 & 0,43 & 0,50 \\
\hline third hierarchical level & 5069 & 0,00 & 1,00 & 0,33 & 0,47 \\
\hline org size is smaller than 100 & 5213 & 0,00 & 1,00 & 0,20 & 0,40 \\
\hline org size is between 100 and 499 & 5213 & 0,00 & 1,00 & 0,40 & 0,49 \\
\hline org size is between 500 and 999 & 5213 & 0,00 & 1,00 & 0,13 & 0,33 \\
\hline org size is 1000 or more & 5213 & 0,00 & 1,00 & 0,28 & 0,45 \\
\hline Ministry & 5262 & 0,00 & 1,00 & 0,42 & 0,49 \\
\hline Agency & 5262 & 0,00 & 1,00 & 0,51 & 0,50 \\
\hline $\begin{array}{l}\text { policy field infrastructure, environment, } \\
\text { agriculture, transportation }\end{array}$ & 5262 & 0,00 & 1,00 & 0,15 & 0,36 \\
\hline policy field finance and economic affairs & 5262 & 0,00 & 1,00 & 0,20 & 0,40 \\
\hline $\begin{array}{l}\text { policy field general government, foreign } \\
\text { affairs }\end{array}$ & 5262 & 0,00 & 1,00 & 0,21 & 0,41 \\
\hline $\begin{array}{l}\text { policy field employment, health, social } \\
\text { protection and welfare }\end{array}$ & 5262 & 0,00 & 1,00 & 0,25 & 0,43 \\
\hline $\begin{array}{l}\text { policy field education, recreation, culture, } \\
\text { religion }\end{array}$ & 5262 & 0,00 & 1,00 & 0,14 & 0,35 \\
\hline policy field other & 5262 & 0,00 & 1,00 & 0,17 & 0,38 \\
\hline $\begin{array}{l}\text { policy field justice, public order, safety, } \\
\text { defence }\end{array}$ & 5262 & 0,00 & 1,00 & 0,15 & 0,35 \\
\hline interaction freq. with responsible minister & 5051 & 1 & 6 & 2,60 & 1,53 \\
\hline male & 5262 & 0,00 & 1,00 & 0,55 & 0,50 \\
\hline female & 5262 & 0,00 & 1,00 & 0,32 & 0,47 \\
\hline sex is missing & 5262 & 0,00 & 1,00 & 0,13 & 0,33 \\
\hline 45 or younger & 5262 & 0,00 & 1,00 & 0,24 & 0,43 \\
\hline age $46-55$ & 5262 & 0,00 & 1,00 & 0,35 & 0,48 \\
\hline age over 55 & 5262 & 0,00 & 1,00 & 0,29 & 0,45 \\
\hline age is missing & 5262 & 0,00 & 1,00 & 0,11 & 0,32 \\
\hline less than 5 years public sector experience & 5262 & 0,00 & 1,00 & 0,08 & 0,27 \\
\hline $5-10$ year public sector experience & 5262 & 0,00 & 1,00 & 0,08 & 0,27 \\
\hline $10-20$ year public sector experience & 5262 & 0,00 & 1,00 & 0,28 & 0,45 \\
\hline more than 20 year public sector experience & 5262 & 0,00 & 1,00 & 0,45 & 0,50 \\
\hline public sector experience not indicated & 5262 & 0,00 & 1,00 & 0,11 & 0,32 \\
\hline
\end{tabular}

Min, max, mean and STD based on weighted data (equal country weights); $\mathrm{N}$ based on unweighted data. 


\section{Appendix D: Correlation table}

\begin{tabular}{|c|c|c|c|c|c|c|c|c|c|c|c|c|c|c|c|c|}
\hline & 1 & 2 & 3 & 4 & 5 & 6 & 7 & 8 & 9 & 10 & 11 & 12 & 13 & 14 & 15 & 16 \\
\hline top hierarchical level & 1 & & & & & & & & & & & & & & & \\
\hline second hierarchical level &,$- 448^{* *}$ & 1 & & & & & & & & & & & & & & \\
\hline third hierarchical level &,$- 407^{* *}$ &,$- 635^{* *}$ & 1 & & & & & & & & & & & & & \\
\hline org size is smaller than 100 &, $090^{* *}$ &,$- 038^{* *}$ &,$- 039^{* *}$ & 1 & & & & & & & & & & & & \\
\hline org size is between 100 and 499 & 0,013 &, $034^{*}$ &,$- 046^{* *}$ &,$- 372^{* *}$ & 1 & & & & & & & & & & & \\
\hline org size is between 500 and 999 & $-0,007$ & $-0,010$ & 0,017 &,$- 191^{* *}$ &,$- 323^{* *}$ & 1 & & & & & & & & & & \\
\hline org size is 1000 or more &,$- 085^{* *}$ & 0,004 &, $069^{* *}$ &,$- 301^{* *}$ &,$- 509^{* *}$ &,$- 261^{* *}$ & 1 & & & & & & & & & \\
\hline agency &, $077^{* *}$ &, $130^{* *}$ &,$- 200^{* *}$ & 0,026 &,$- 028^{*}$ &, $050^{* *}$ &,$- 030^{*}$ & 1 & & & & & & & & \\
\hline Ministry central &,$- 182^{* *}$ &,$- 072^{* *}$ &, $231^{* *}$ & $-0,004$ & $-0,012$ &,$- 053^{* *}$ &, $057^{* *}$ &,$- 870^{* *}$ & 1 & & & & & & & \\
\hline policy field infra, env, etc. & 0,020 & $-0,006$ & $-0,011$ &,$- 036^{* *}$ &, $035^{*}$ &, $065^{* *}$ &,$- 058^{* *}$ &, $034^{*}$ &,$- 061^{* *}$ & 1 & & & & & & \\
\hline $\begin{array}{l}\text { policy field finance and economic } \\
\text { affairs }\end{array}$ &,$- 039^{* *}$ &, $029^{*}$ & 0,004 &,$- 045^{* *}$ & 0,021 & 0,009 & 0,009 &,$- 030^{*}$ &, $030^{*}$ &,$- 075^{* *}$ & 1 & & & & & \\
\hline $\begin{array}{l}\text { policy field general government, } \\
\text { foreign affairs }\end{array}$ & $-0,025$ & 0,012 & 0,010 & $-0,018$ & 0,023 & $-0,008$ & $-0,003$ &,$- 060^{* *}$ &, $089^{* *}$ &,$- 084^{* *}$ &,$- 077^{* *}$ & 1 & & & & \\
\hline $\begin{array}{l}\text { policy field employment, health, } \\
\text { etc }\end{array}$ &,$- 030^{*}$ & 0,021 & 0,005 &,$- 030^{*}$ &,$- 047^{* *}$ &,$- 035^{*}$ &, $103^{* *}$ &, $132^{* *}$ &,$- 122^{* *}$ &,$- 143^{* *}$ &,$- 189^{* *}$ &,$- 182^{* *}$ & 1 & & & \\
\hline $\begin{array}{l}\text { policy field education, recreation, } \\
\text { culture, religion }\end{array}$ &, $065^{* *}$ & $-0,012$ &,$- 045^{* *}$ &, $101^{* *}$ & 0,023 & $-0,012$ &,$- 101^{* *}$ &, $040^{* *}$ &,$- 037^{* *}$ &,$- 098^{* *}$ &,$- 149^{* *}$ &,$- 144^{* *}$ &,$- 169^{* *}$ & 1 & & \\
\hline policy field other & $-0,002$ & 0,007 & $-0,006$ & 0,018 &, $048^{* *}$ &, $041^{* *}$ &,$- 099^{* *}$ & 0,021 &,$- 050^{* *}$ &, $043^{* *}$ & $-0,006$ & 0,012 &,$- 122^{* *}$ & $-0,023$ & 1 & \\
\hline $\begin{array}{l}\text { policy field justice, public order, } \\
\text { safety, defence }\end{array}$ &, $076^{* *}$ & $-0,025$ &,$- 040^{* *}$ & 0,011 & $-0,006$ & $-0,005$ & 0,001 & $-0,017$ & 0,016 &,$- 077^{* *}$ &,$- 128^{* *}$ &,$- 112^{* *}$ &,$- 173^{* *}$ &,$- 127^{* *}$ &,$- 097^{* *}$ & 1 \\
\hline $\begin{array}{l}\text { Interaction freq.: Responsible } \\
\text { minister }\end{array}$ &, $326^{* *}$ &,$- 090^{* *}$ &,$- 190^{* *}$ & $-0,004$ &, $103^{* *}$ & $-0,021$ &,$- 090^{* *}$ &,$- 338^{* *}$ &, $231^{* *}$ & 0,010 &,$- 035^{*}$ & 0,027 &,$- 048^{* *}$ &, $031^{*}$ &,$- 037^{* *}$ & ,056 \\
\hline resp is female &,$- 109^{* *}$ &, $045^{* *}$ &, $048^{* *}$ & 0,002 &, $039^{* *}$ & 0,019 &,$- 058^{* *}$ &, $041^{* *}$ & $-0,009$ &,$- 062^{* *}$ & $-0,013$ &, $031^{*}$ &, $036^{* *}$ & 0,025 &, $041^{* *}$ &,- 06 \\
\hline resp is male &, $124^{* *}$ &,$- 045^{* *}$ &,$- 061^{* *}$ & $-0,007$ &,$- 029^{*}$ & 0,002 &, $035^{*}$ &,$- 027^{*}$ & $-0,008$ &, $060^{* *}$ & 0,005 & $-0,023$ &,$- 043^{* *}$ & $-0,019$ &,$- 051^{* *}$ & ,086 \\
\hline 45 or younger &,$- 123^{* *}$ &, $033^{*}$ &, $073^{* *}$ & $-0,020$ &, $068^{* *}$ &,$- 029^{*}$ &,$- 033^{*}$ &,$- 033^{*}$ &, $051^{* *}$ & $-0,003$ &, $029^{*}$ &, $041^{* *}$ &,$- 030^{*}$ &,$- 028^{*}$ & 0,023 & $-0,0$ \\
\hline age $46-55$ & $-0,009$ & 0,009 & $-0,002$ & $-0,012$ &,$- 037^{* *}$ &, $030^{*}$ & 0,026 & $-0,007$ & 0,008 & $-0,005$ & $-0,002$ & 0,000 & $-0,001$ & 0,007 & $-0,005$ & ,043 \\
\hline age over 55 &, $144^{* *}$ &,$- 040^{* *}$ &,$- 083^{* *}$ &, $031^{*}$ & $-0,016$ & 0,011 & $-0,017$ &, $048^{* *}$ &,$- 069^{* *}$ & 0,013 &,$- 040^{* *}$ & $-0,025$ & 0,020 & 0,024 & $-0,021$ & $-0,0$ \\
\hline $\begin{array}{l}\text { less than } 5 \text { years public sector } \\
\text { experience }\end{array}$ & $-0,021$ &, $074^{* *}$ &,$- 057^{* *}$ & 0,011 &, $065^{* *}$ & $-0,016$ &,$- 067^{* *}$ & 0,016 & 0,005 &,$- 034^{*}$ &, $062^{* *}$ & $-0,001$ & $-0,007$ & 0,003 &, $033^{*}$ &,- 02 \\
\hline 5-10 year public sector experience &,$- 050^{* *}$ & 0,014 &, $028^{*}$ & 0,024 &, $035^{*}$ & $-0,022$ &,$- 041^{* *}$ &, $046^{* *}$ &,$- 034^{*}$ & 0,011 & 0,018 & $-0,021$ & 0,013 & $-0,008$ & 0,008 &,- 03 \\
\hline $10-20$ year public sector experience &,$- 070^{* *}$ &, $033^{*}$ & 0,027 & $-0,011$ &, $067^{* *}$ &,$- 038^{* *}$ &,$- 034^{*}$ & 0,018 & 0,002 & $-0,017$ & $-0,002$ &, $059^{* *}$ & 0,015 & 0,001 & 0,014 &,- 03 \\
\hline $\begin{array}{l}\text { more than } 20 \text { year public sector } \\
\text { experience }\end{array}$ &, $118^{* *}$ &,$- 067^{* *}$ &,$- 033^{*}$ & $-0,007$ &,$- 100^{* *}$ &, $064^{* *}$ &, $063^{* *}$ &,$- 041^{* *}$ & 0,005 &, $041^{* *}$ &,$- 048^{* *}$ &,$- 032^{*}$ & $-0,022$ & 0,006 &,$- 031^{*}$ & ,078 \\
\hline
\end{tabular}

${ }^{\mathrm{i}}$ The original questionnaire contained three items to measure direct politicization each capturing a different dimension of the phenomenon. All were measured using a 7-point Likert scale ranging from totally disagree to totally agree. Although the three items load on a single factor for the entire dataset, explaining $46,3 \%$ of variance, the Cronbach's Alpha remains low, and separate analysis on the individual countries shows that in the Netherlands and Denmark, two clearly distinct factors emerge, which are furthermore different across these two countries. This means there are cross-country validity issues with the scale. While this is in itself worth examining further, it is not the purpose of this article. 